\title{
会長講演
}

\section{Oddi 筋の外科臨床}

\author{
弘前大学第 2 外科 \\ 小野慶一 \\ SURGERY OF THE SPHINCTER OF ODDI
}

\section{Keiichi ONO}

Department of Surgery, Hirosaki University School of Medicine

Oddi 括約筋の胆道生理上に果す役割について検討するとともに胆道 drainage 手段としての経十二 指腸括約笳形成術（TSP）症例の長期 follow up を行いその有効性を再確認した。すなわち臨床例に より胆汁排出に打ける Oddi 筋の peristaltic pump 説の詥りであること，また Oddi 筋と migrating motor complex との相関を観察することにより同筋の十二指腸よりの独立性をそれぞれ明らかにし た.さらに Oddi 筋に対する各種消化管ホルモンの作用を明らかにするとともに，摂食時における Oddi 筋運動の多様珄を scintigraphy により具体的に明示した。

TSP 施行後 3 年以上経過した胆桠疾患117例の長期 follow upによりその有勃率は83.7\%であるこ とを述べた。

索引用語 : Oddi 筋, migrating motor complex, 消化管ホルモン, 胆道シンチダラフィー, 経十二指腸括約笳形成術

はじめに

著者 ${ }^{1}$ は1982年 7 月, 第20回日本消化器外科学会総 会に括いて，代田明郎会長より宿題報告「十二指腸乳 頭部を中心とした胆道の生理と病態」の担任を命ぜら れ, Oddi 括約筋の胆脞疾患における重要性について報 告し, あわせて外科的見地に扔ける乳頭部手術の本来 のあり方について著者の見解を示した.

今回会長講演の機会を与えられ, Oddi 筋を中心とし た胆汁排出機序の生理に関するその後の研究成果なら びに胆汁うっ滞解除手段としての経十二指腸括約筋形 成術（TSP）140例のらち, 近接例をのぞく117例の長 期術後成績について検討した結果，若干の知見を得る ことができたのでここに報告する。

\section{I. 括約筋運動と胆汁排出機序}

最近 Oddi 筋運動の促進により胆汁排出が促がされ るという peristaltic pump説23)あるいは active pump 説 () と Oddi 筋運動抑制時にこそ胆汁排出が行

\footnotetext{
※第28回日消外会総会

$<1986$ 年12月10日 $>$ 別刷請求先：小野 慶一

厂036 弘前市在府町 5 弘前大学医学部第 2 外科
}

われるといら全く相反する説らとが対立し，決着が得 られていない。この問題は胆道生理学上もつとも基礎 的かつ重要な問題之考学られる。

教室 ${ }^{6)}$ に扔いては Arndorfer ら $ら^{7} の$ hydraulic capillary infusion system を応用し, 臨床的に PTCD 管を 利用して Oddi 笳内腔の圧变化と $35 \mathrm{~mm} \mathrm{X}$ 線映画によ

図 1 SO activity $の$ phasic contraction は造影棛の 十二指腸内流出を阻止, 中断する。弛楥期淿一致し て流入される。

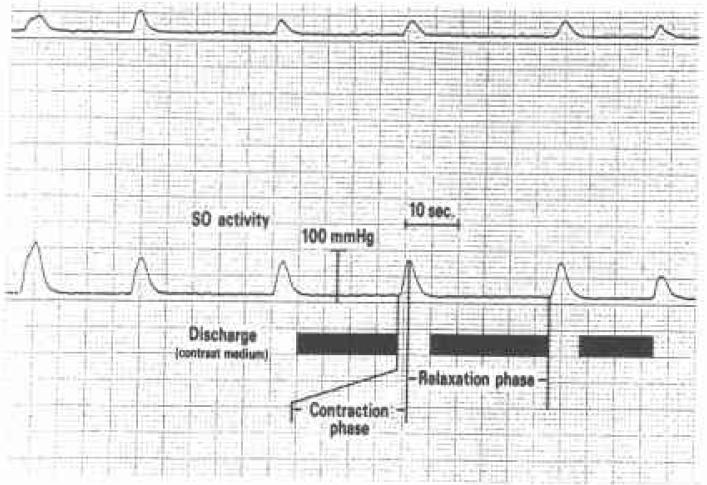


る造影剂つまり胆汁流出との同時観察を行った.

すなわち图 1 のごとく sphincter of Oddi （SO） activityつまり Oddi 括約筋の phasic contraction $に$ 一致乙て造影剂流出は中断され, SO relaxationの時 期に胆汁流出は許容されるという Oddi ${ }^{819)}$ Boyden ${ }^{10)}$ の形態学的論拠を裏付ける結果となった。具 体的に述べると，図 2 上のごとく $35 \mathrm{~mm}$ film に同時記 録された内圧カーブは phasicの立上り変化をみせ,同 時に映像上の narrow distal segment（NDS）は細小

図 2 PTCD route より内王測定用 catheter 総胆 管内に挿入, NDS 内腔の压変化を $35 \mathrm{~mm} \mathrm{X}$ 線映画 の画面コーナーに同時記録する，総胆管内に結石陰 影 2 個存在している。
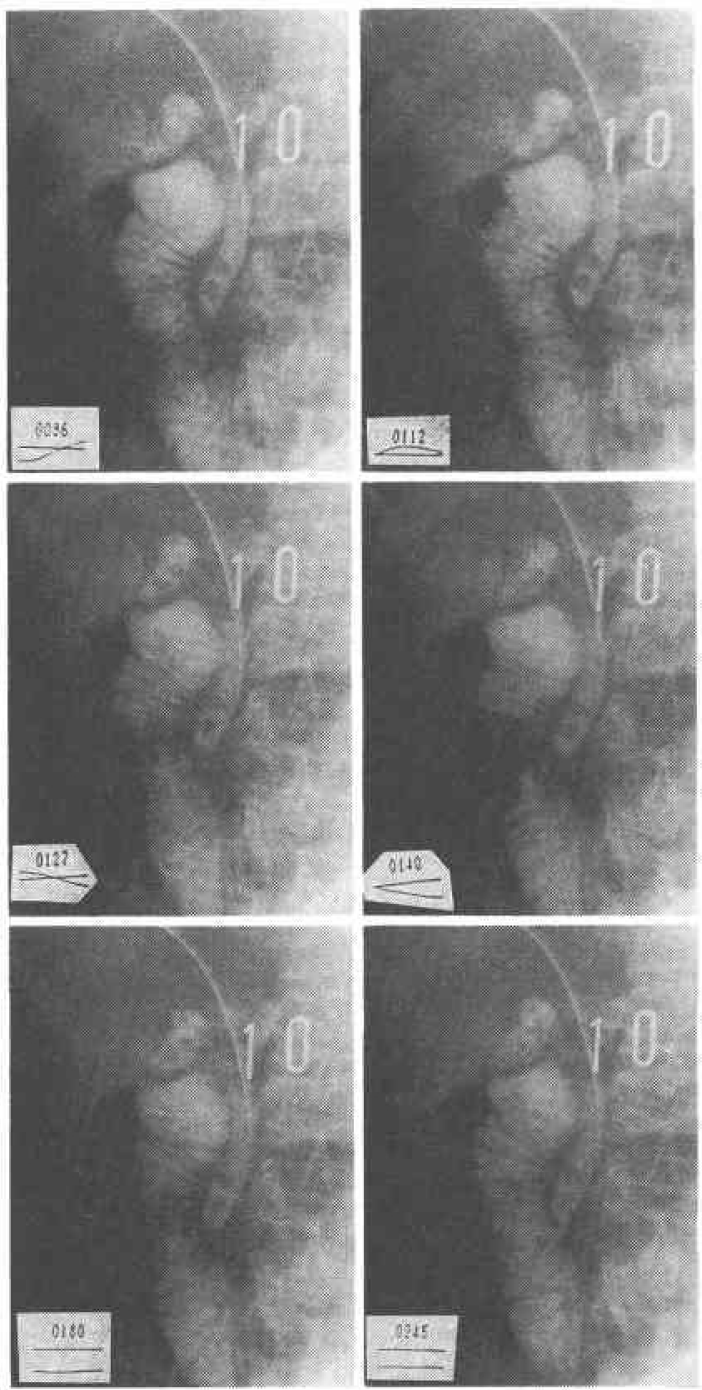

図 3 a : 総胆管結石患者の術前 SO activity (PTCD route), phasic contraction は全般的に抑制されて いる. b: 結石除去後 20 日目, 術前に比べ著しく回復 している.

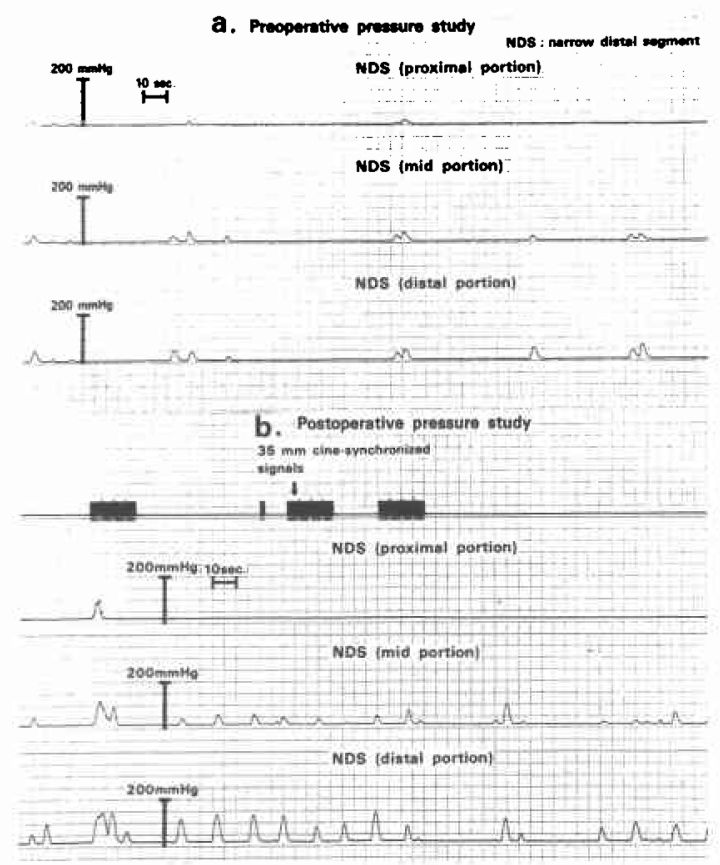

化する．図 2 中では内圧カーブは下降し基線と交叉す る. 同時にNDS は中断した. 図 2 下では内圧カーブは 静止し基線と平行する.NDS は再び上方からふくらみ 始め, No. 245でもっとも広く開大し, 造影剂は十二指 腸に流入する。

結局 Oddi 筋運動の促進時には胆汁流出は中断さ れ，その抑制時に胆汁の十二指腸内流出は許容される あのと考えられる.

図3a は総胆管内に数コのコレステロール系混合石 が存在する症例の術前 NDS の triple lumen catheter による上，中，下 3 個所の SO activity である。いずれ 6 phasic contraction は立上りるゆるやかで振幅，頻 度ともに低下した状態にある. 図3b は手術により結石 除去を行って20日目の観察であるが，同図 $\mathrm{a}$ と対応す るいずれの波形む急峻となって著明に回復, 改善され ている. シェーマで示せば図 4 の術前上段のごとく， 收縮振幅子低く，収縮間隔も疎でしか子造影剤流出も 不活発だったものが，下段のごとく結石除去後は振幅 む大に間隔も頻回となり造影剤流出む活発に，律動的 に力強く十二指腸に注ぎこまれていることがよくわか る. 
図 4 図 3 をシェーマで示したもの. 手術による結石 除去後下段のごとくSO activity は力強く律動的と なる。

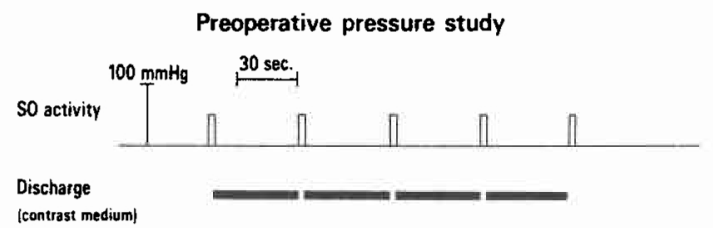

Postoperative pressure study

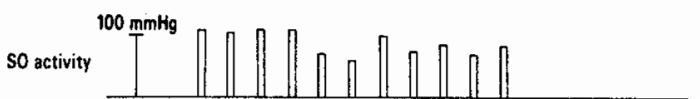

Discharge [contrast medium]

図 5 catheter pressure transducer (MIKRO-TIP) による MMCの観察 (phase I). G：青，D：十二指 腸, $\mathrm{SO}_{1}$ : NDS proximal portion, $\mathrm{SO}_{2}: \mathrm{NDS}$ distal portion. 胃・十二指腸は運動静止期つ屯り MMC phase I を示しているが，SOつまり Oddi 筋 はこれらと無関係に周期的な運動をくりかえしてい る.

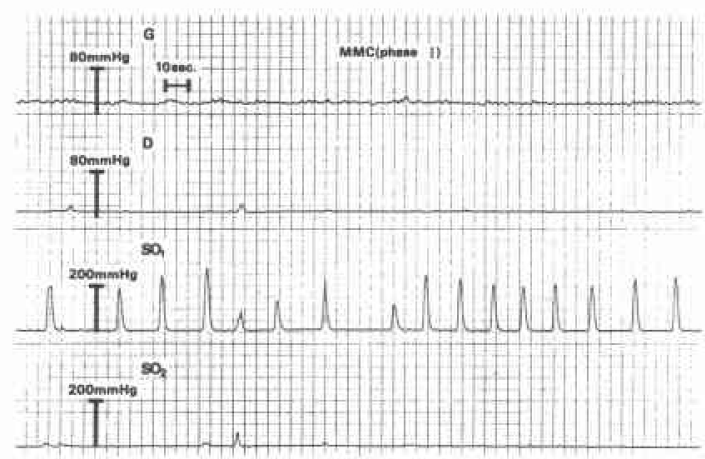

つまり結石保有という胆道病態が SO activityに与 える抑制効果の大きいことがよくらかがわれよう。こ の状況が悪循環的に胆汁らつ滞を増悪し，結石形成の さらに促進されることが容易に推察される。また結石 保有例の胆道内圧測定上の陥し穴も示唆され, pressure studyにおける慎重な対応が望ましいものと考党 られる。

\section{II. migrating motor complex と括約筋運動}

最近消化管運動生理に执いては空腹時上位消化管よ り下行性の周期的収維伝播すなわち migrating motor complex $(\mathrm{MMC})^{11) \sim 13)}$ みられることは汪定説と なっている，そこで教室鈴木らは MMC と括約笳運動
図 6 gastric phase III ๖り数秒の time lagをもっ て十二指腸 (D) にこれが伝播され，これに呼応して $3 ー 4$ 個からなるSO contraction も出現する。

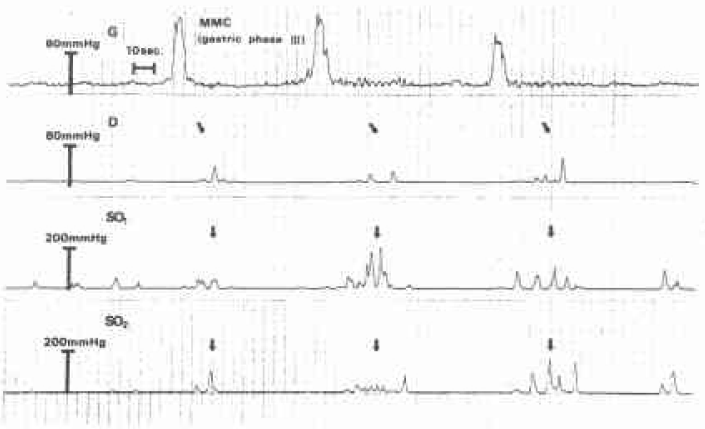

との相関について検討した。

図 5 は catheter pressure transducer (MIKRO. TIP) によるMMCの臨床観察例で胃 (G), 十二指腸 (D), NDS, Oddi 筋の proximal portion $\left(\mathrm{SO}_{1}\right)$, distal portion $\left(\mathrm{SO}_{2}\right)$ からの同時運動波形をそれぞれ示して いる、すなわち胃，十二指腸は phase Iつまり運動静 止期にあるが, Oddi 筫はこれらと無関俰に 1 分 4 回前 後の phasic contraction 周期的にくり返している. この状態は測定開始より40分持続したのち，胃十二指 腸運動は間歇的に収縮波の出現する phase IIに移行 し, 振幅, 頻度ともに次第に増加した。

図 6 は phase II 出現15分後のbので，胃（G）には phase IIIつまり 1 分 1 回程の strong contraction が 出現して，これが数秒の time lagをもって十二指腸 (D)に伝播され，これに呼応して 3 亿 個からなる SO contraction が出現するが，十二指腸は phase II の状 態である。

図7は図6の 2 分後に出現した duodenal phase III で十二指腸に 1 分 1 回の強い収縮運動が 5 分間にわた り継続して出現し, SO activity もこれに呼応して著明 なえ進状態となった。この際胆管内に造影剤を持続注 入しても，十二指腸内に全く排出されなかったことか 5, MMC phase III では胆汁の十二指腸内流入は完全 に抑制されるものと思われる。

図 8 は再び phase I に復帰した MMCの状況で, SO activityももとのリズムにもどっている.

すなわら Oddi 笳運動は基本的には十二指腸運動か ら独立しており, phase III に際してはこれと協力的に 亢進するが，これは胆汁の十二指腸流出の阻止抑制効 果を有するものと考觉られ, refilling phase との関連 
図 7 duodenal phase III では十二指腸の運動立進に 呼応して, SO activity も著明な亢進状態を示した。

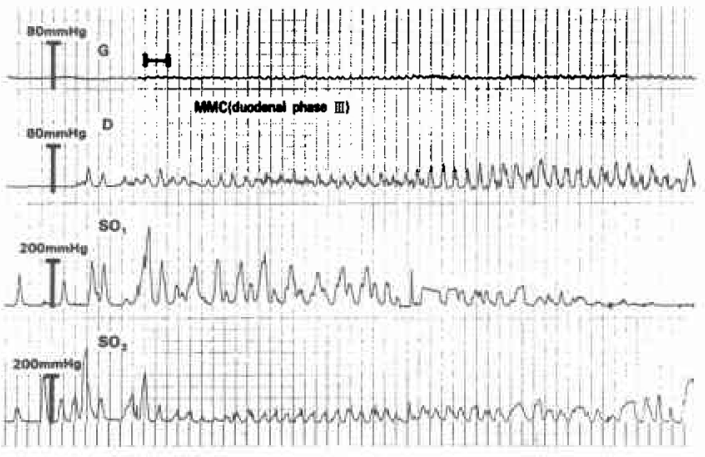

図 8 MMCがphase I に復㷌したところで, SO activity もとのリズムに戻っている.
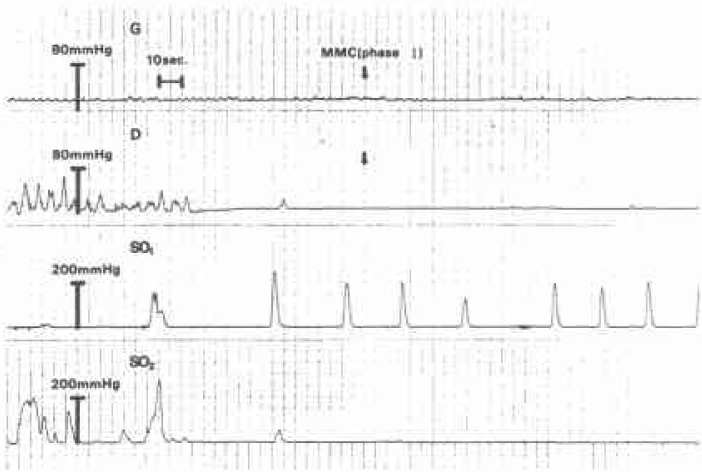

も示唆される，いずれにしてす今後の詳細な検討が必 要であろら。

III. 括約筋運動と消化管ホルモン

cholecystokinin (CCK) は胆変収縮を促進する事実 についてはとくに異論はない.けれどす Oddi 筋への 作用についてはその運動を㧕制するという点で大方の 意見は一致しているものの，中にはその運動を元進す ると主張する研究者1415) むいてかならずしも一定した 見解が得られていない。

そこでわれわれは1617)成人男子 volunteer 5 名につ いて外因性 CCK 投与を行い超音波断層法による胆栾 面積の継時的計測と radioimmunoassayによる plasma CCK 濃度の同時測定を行った。その結果図 9 に示 すごとく CCK-33 $(0.03 \mathrm{u} / \mathrm{kg})$ を10分間持続静注する と，投与前 $7.5 \mathrm{pg} / \mathrm{ml}$ 以下であった plasm CCK 濃度は 投与後 3 分で上昇し, 10 分後に最高値 $25.5 \pm 8.2 \mathrm{pg} / \mathrm{ml}$ となり，25分はどで投与前のレベルに回復した。胆跬 収縮曲線は phasma CCK レベルと逆向きの上に開い
図 9 plasma-CCK 濃度が上昇するのと一致して，胆 㖶収縮曲線は急降下し, CCK 濃度の復㷌と一致し て，収線曲線は refilling phaseに移行する。

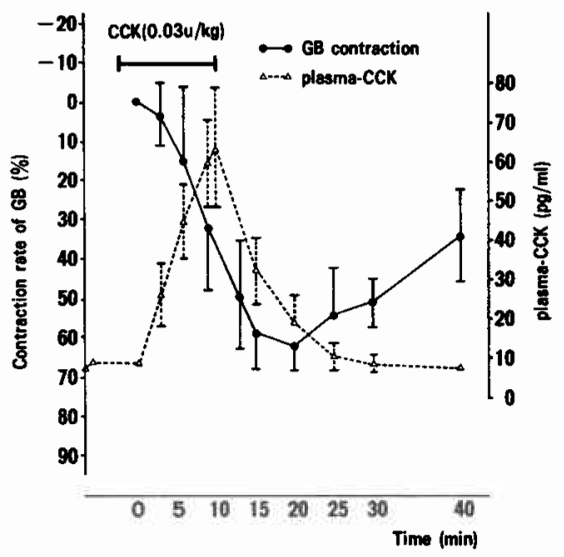

図10 CCK 投与後20分前後まで SO activity は振幅， 频度ともに著明に抑制される。
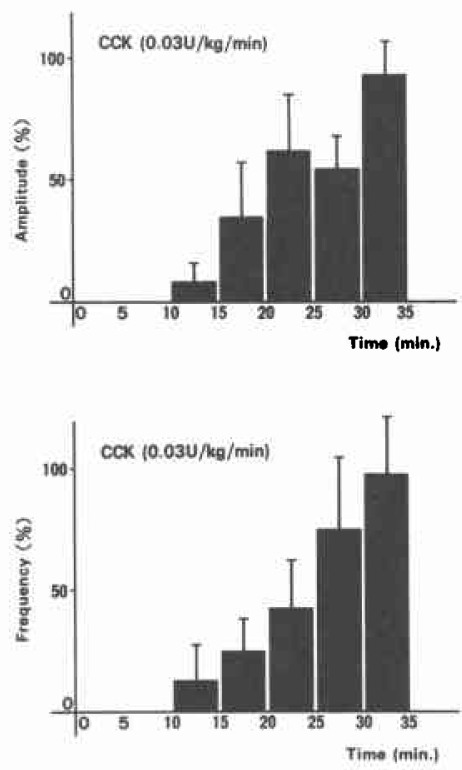

たカーブを画き，収縮開始後20分で最大収縮率62\%と なり，その後 refilling phaseに移行した。

つぎ胆譱摘出後の患者 4 例について前述の hydraulic capillary infusion system により, PTCD tubeを介して triple lumen catheter NDSに下降 性に插入し Oddi 筋運動の計測を行った。なお No.7F catheter pressure transducer (MIKRO-TIP) を用い て胃十二指腸運動の同時測定も行った。 
図11 Oddi 筋運動は plasma-CCK 濃度とよく相関し ている. CCK 投与後 Oddi 筋運動は抑制されこそす れ, 六進はしない。
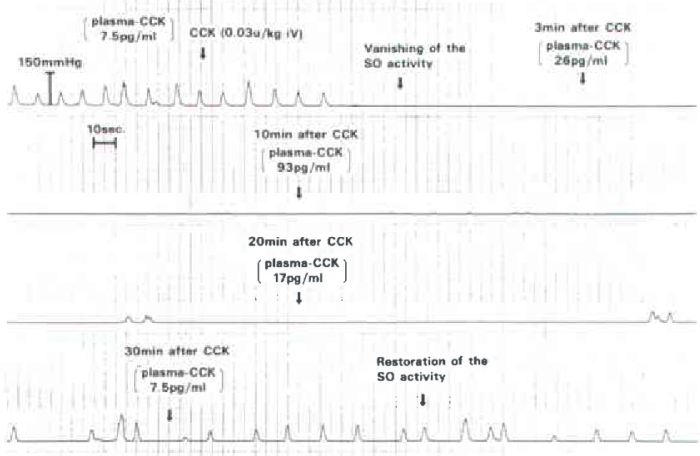

図12 CCKによって著明に開大した十二指腸乳頭開 口部。総胆管と主荤管を隔てる隔壁がのぞかれる。
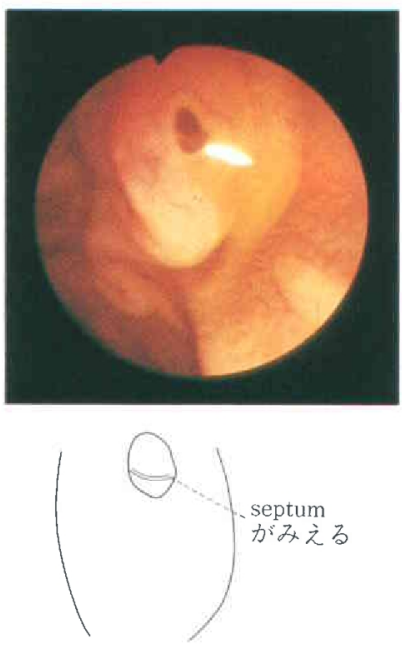

すなわち図10のごとく phasic contraction における 投与前の振幅, 頻度をいずれも $100 \%$ とすると, 振幅は 投与後 10 分間完全消失し，やがて少しつう回復して20 分前後まで抑制状態がつづき30分頃より投与前のレベ ルに回復した。頻度も同様に経過し，20分頃まで著明 に抑制され，30分で投与前に泀ぼ回復した。

実際の Oddi 筋運動記録を観察すると図11のごと く, CCK 投与後 1 分15秒ほどで phasic contraction は 完全消失した。plasma CCK は 3 分後 $26 \mathrm{pg} / \mathrm{ml}$ と上昇 する. 10 分後 $93 \mathrm{pg} / \mathrm{ml}$ と最高となり，20分後低下して $17 \mathrm{pg} / \mathrm{ml}$, やがて30分後には投与前の $7.5 \mathrm{pg} / \mathrm{ml}$ となっ て SO activity は回復した。

この Oddi 筋運動抑制時には，図12のごとく十二指
腸乳頭部は完全に大きく開大し，淡黄色の胆汁が絶え 間なく十二指腸挖内に流入され，総胆管と主膵管との 隔壁がいみじくも開口部を通して直視することができ た。この状況を film に收めてあるが，この隔壁の上部 が主膵管, 下部が総胆管で, 膵液排出の時はこの隔壁 が下に，胆汁排出の際は上方にそれぞれシフトするの を観察することが出来た。

以上の観察結果から外因性 CCK 投与後, plasma $\mathrm{CCK}$ 濃度の上昇により胆囊は収縮を来し, 同時に Oddi 竻運動は抑制され，その間に打いて胆汁は一挙に 十二指腸に注ざこまれる。そして胆囊が refilling phase に移行するに従って Oddi 筋運動も回復するこ

図13 caerulein 投与に上り a) SO 波形の消失， b) 抑制状態がつづき，c）35分頃に本来の波形に回復し t.
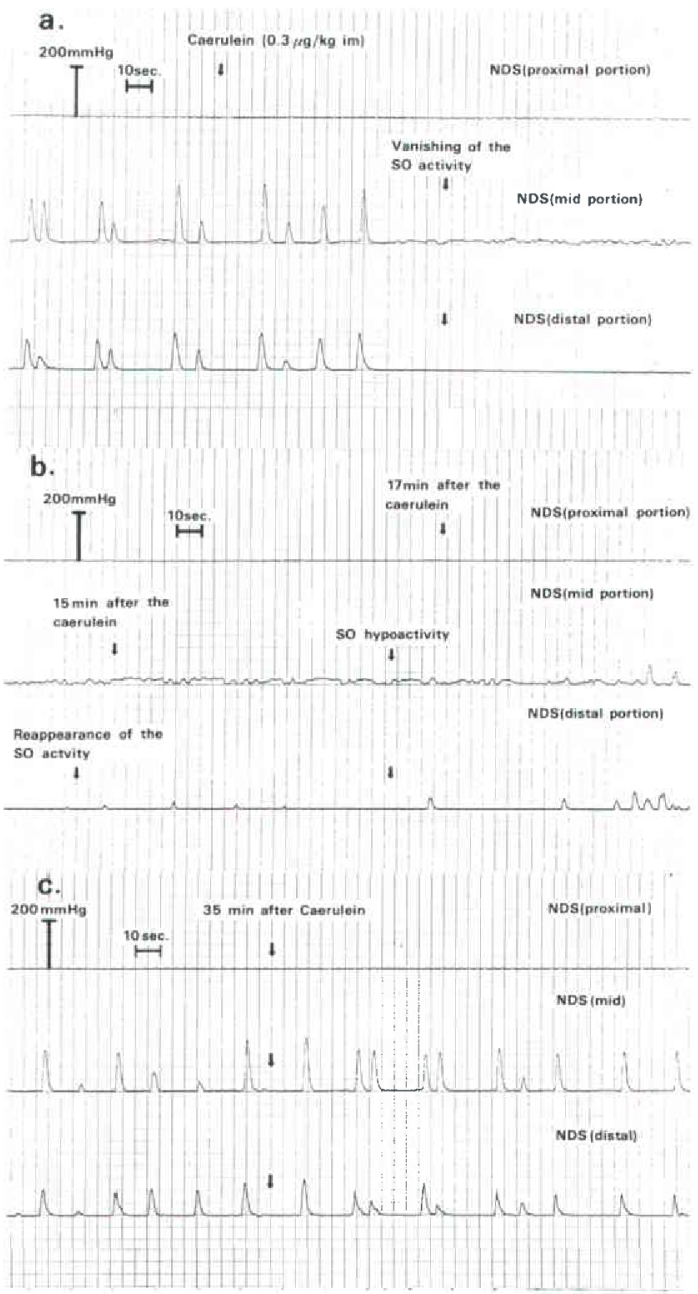
とが明らかとなった。人体に関する限りほかの動物に ついてはともかくとして CCKによって Oddi筋運動 の克進することはまずありえないものと考觉られる。

CCKよりも胆囊収縮薬理作用がはるかに著明な caerulein 投与により Oddi 筋運動はその頻度ならび に振幅もかなり抑制される。具体例について観察する と, 図13a のごとく caerulein $0.3 \mu \mathrm{g} / \mathrm{kg}$ の筋注によ り，李もなくSO activity は完全に消失し，図13bのご とく15分頃より低振幅の波形が少しづつ出現してく る。依然として抑制状態が継続し，図13c のごとく35分 頃になってやっと本来の運動波形に回復した。

実際の胆汁排出に及ほす caeruleinの効果を $35 \mathrm{~mm}$ X線映画にて観察し図14のごとく映像分析を行った。 すなわち ERCPにて胆囊を造影剤にて充満しておき， caerulein 投与すると, 3 分，5分，7分，10分，15 分々継時的に胆霬は樎小し，同時に総胆管が搪張し， やがて十二指腸内に造影剤が排出されてゆき，15分で 胆囊は完全に空虚となった。その間 Oddi 筋運動なら びに十二指腸はほぼ静止状態を示し，前述のごとく30 分頃より本来の運動波形:回復することは前述の通り である。

东た pinhole collimatorを用いた肝胆道 scintigra. phyによる観察でも caerulein 投与後15分までに胆囊 内の RI は任とんど全部十二指腸内に排出された。こ

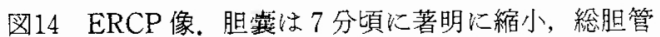
が拡張, 十一指腸が造影剤で満され，15分頃には胆 囊が完全に空虚となった。

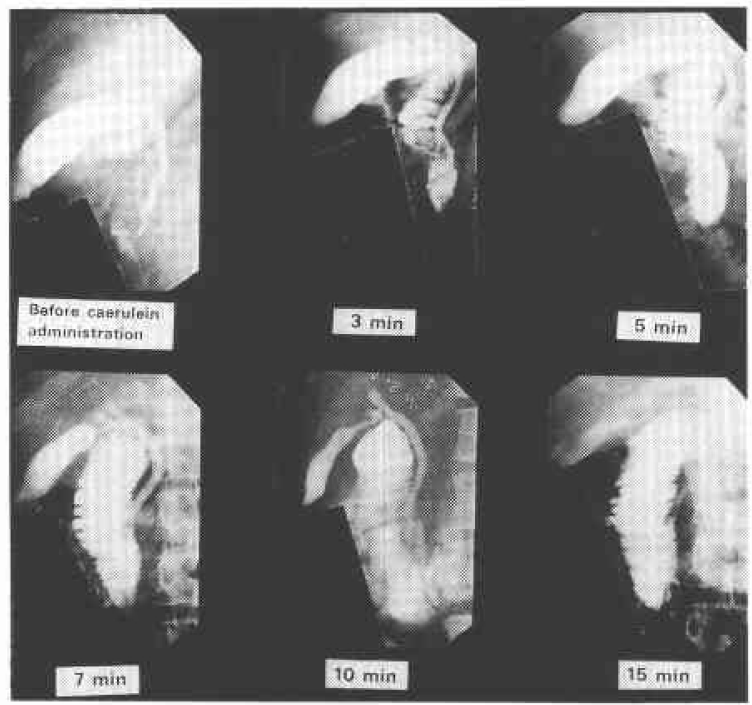

涵15 caerulein 投与時 time activity curve，投与後 数分で胆萤，総胆管のカーブは急降下゙し，十二指腸 カーブが急上昇する。

\section{Time activity curve}

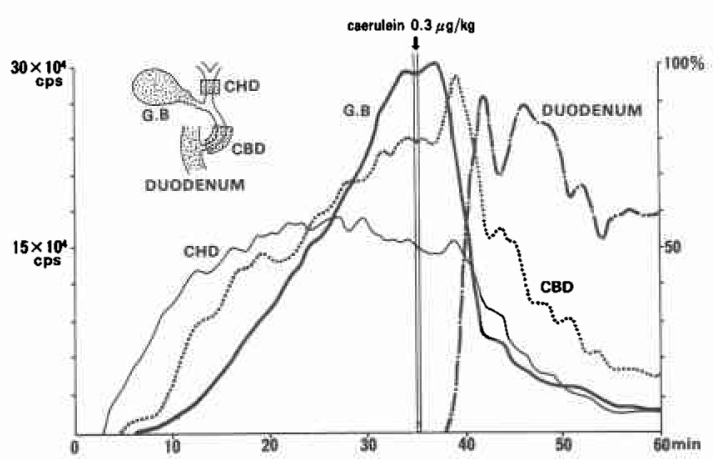

の現象を time activity curve で観察しても图15のご とく caerulein 投与後数分で胆䨳，総胆管の activity curveは急降下し，逆に十二指腸カーブが急上昇する 経過がよく観察された。

以にの結果から CCK や caerulein 投与時には, 急速 な胆筫收縮とあいまって Oddi 笳運動は消失ないしは 抑制され，その時期に一致して胆汁の十一指腸内排出 が行われるものと考文られる。したがっていわゆる peristaltic pump 説惊りであることが明白と思われ る.

\section{VI. 肝胆道 scintigraphyによる括約筋運動の観察}

教室 ${ }^{16) 18)}$ に执いては最近になり parallel collimator にかわり pinhole collimatorを用いた肝胆道 scintigraphy を実施し，より詳細な胆汁排出機序について観 察を重悋ている。

その結果空腹時胆汁排出機序において Oddi 竻動態 のいかんにより拈よそ 4 通りの動態 pattern が観察さ れ，しかも日を改めて再検すると，かならずしも同一 の patternを示すとは限らず，相互に他の patternに 移行しらるものであることが明らかとなった。換言す れば個体の身体的条件により胆汁排出の状況も種々な 様相を呈するものと考えられ，極めて複雑なメカニズ ムであることが推察される。

そこで摄食時に抢ける胆汁排出動態はどのように なっているものか, 教室の福島が volunteer 30例につ いて検討した。すなわち図16左のごとく，摂食前は RI の大部分は胆囊内に貯溜され，わずかに総胆管がみら れるが，十二指腸には RI は全く出現していない.そし $\tau$ test meal (glucose $33.4 \mathrm{~g}$, protein $6.7 \mathrm{~g}$, lipid $4.4 \mathrm{~g}$ ) 
図16 test meal 捸食により胆襄は収縮し，総胆管が RI で濃厚化, 一部は左肝管へ逆流する (左). time activity curve は揸食直後 RI が肝管 (CHD) に逆流 してから降下，十二指腸に排出される（右）。
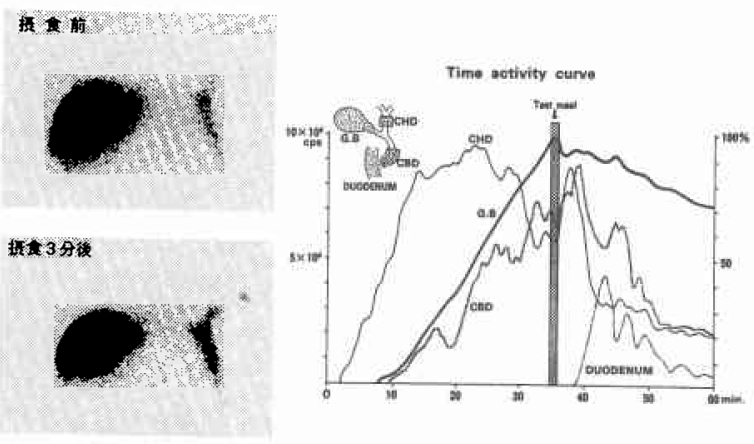

図17 摂食前 RI がすでに十二指腸に出現していた例 では，摂食後 4 分で十二指腸への排出はさらに著明 となり，上部肝管への逆流現象はみられない。
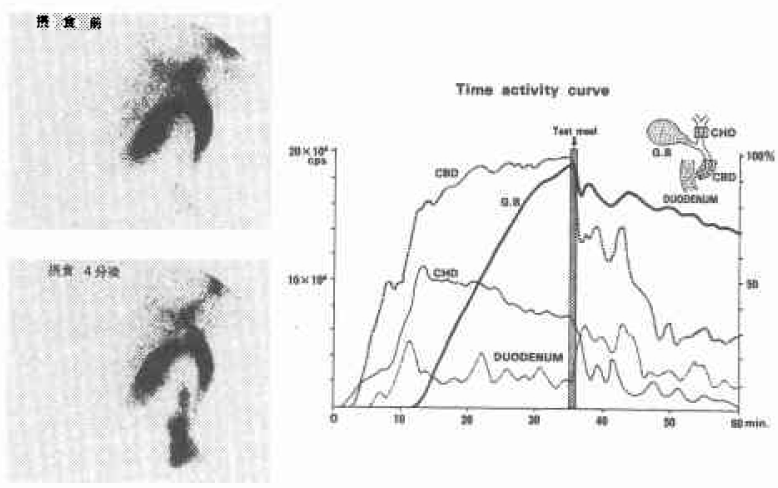

を30〜60秒かけて $200 \mathrm{ml}$ を摂食せしめると 3 分後に， 胆囊は若干収縮し, 総胆管はRI で濃厚化し, しか子左 肝管へ RI の逆流現象がみられた。この時点で十二指 腸へは RI が末だ出現していない。

time activity curveをみると図16右のごとく， test meal 投与前に沶いては Oddi筋緊張維持のためか十 二指腸に RI は出現していない，摂食にひきつついて 胆囊 (GB) は急速に減少し， RI は総胆管 (CBD), 総 肝管 (CHD) 八移行し，やがて７分頃よりこれらは減 少し始め, 初めて十二指腸に RIが出現するようにな る. 換言すれば Oddi 筋緊張時に摂食した場合, 肝外胆 道系は胆汁で充満され，一部左肝管への逆流現象まで 伴ない，やがて Oddi 筋開放王まで総胆管が充満する と始めて RI は十二指腸に排出されるものと考えら れ，その経過が具体的によくうかがわれた。このよら な Oddi 筋緊張群は15例みられそのうち10例つまり
67\%に肝管内逆流が観察された。

図17左は摂食前 RI がすでに十二指腸に出現してい た例の経過を示すが，摂食後 4 分で十二指腸への排出 はさらに著明となり, 前図のような上部肝管への逆流 現象はみられない，図17右はその time activity curve であるが，摂食後胆蛪，総胆管，総肝管いずれるその カーブは下降して十二指腸へ排出され逆流現象はみら れなかった，換言すれば Oddi 筋繁張の低下している 場合の胆汁排出 pattern と考兄られる。このような例 は15例にみられ，逆流現象は 2 例 (13\%) にしか観察 されなかった，従って摂食による胆汁排出動態は摂食 前の Oddi 筋緊張状態によってかなり変化し得るもの であることがうかがわれる。

以上のように Oddi 筋運動の背景は肝分泌, 消化管 ホルモン, MMC cycle, 胆囊動態, 摂食, その他種々 の要因によって，かなり奥行の深いひろがりをもつも のであり, 単純に映像変化や, 内圧測定などの一過性 観察によって早計にすべてを解釈することは敩に慎ま ねばならないと考学られる。したがって胆道精査法な どもあくまです補助的手段であることに徹し，診断， 適応決定には上述のような Oddi 筋生理学などの基本 的認識に立脚して, natural historyを始め広い視野を 展開してのぞむ必要があろら。

V. 経十二指腸括約筋形成術 (TSP) の長期経過観察 教室においては1973年以来1985年までに, 胆汁・膵 液のうっ滞解消を目的とした胆道 drainage 手術とし ての TSPを140例に対し施行した。 その間術式の細部 にわたっての改良につとめ ${ }^{19)}$ ，例党ば図18のごとく教 室関連病院の見滝伸忠博士（三戸町立病院副院長）の 協力により，従来の乳頭把持鉗子20) 22)を改良し，深部 での手術操作に適するよう二段の屈曲をもたせ，しか もその角度を少しづ変えた数種類のサイズのものを

\section{図18 小野・見滝乳頭把持鉗子}

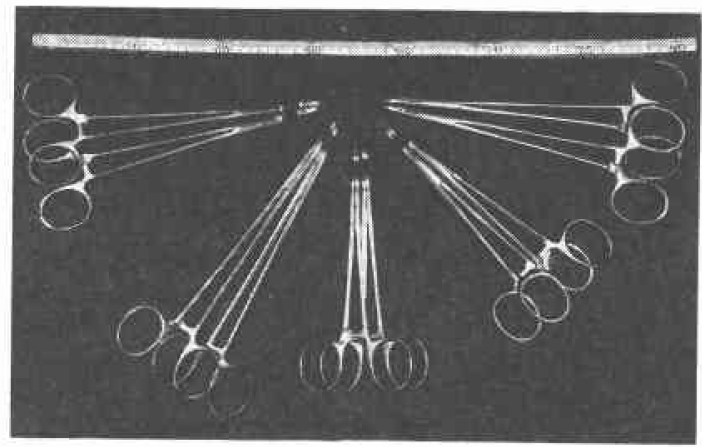


表 1 乳頭部手術直接死亡率の比較

\begin{tabular}{|c|c|c|c|}
\hline & al cases & $\mathrm{n}$ & $\%$ \\
\hline 槙·小野，1960 & 24 & 1 & 4.1 \\
\hline Olivier, 1965 & 108 & 7 & 6 \\
\hline Mouchet, 1965 & 180 & 12 & 6 \\
\hline Roux, 1965 & 148 & 8 & 5.4 \\
\hline Arianoff, 1966 & 285 & 5 & 1.7 \\
\hline Saleabier, 1965 & 138 & 11 & 7.9 \\
\hline Flabeau, 1967 & 100 & 8 & 8 \\
\hline Hivet, 1968 & 340 & 14 & 4 \\
\hline Stoppa, 1968 & 240 & 11 & 4.5 \\
\hline Bothaig S（27報告例の集計），1969 & 5750 & 244 & 4.2 \\
\hline Suire. 1972 & 100 & 6 & 6 \\
\hline Jones, 1973 & 284 & 4 & 1.4 \\
\hline Lataste, 1974 & 250 & 17 & 6.8 \\
\hline Stefanini, 1975 & 510 & 14 & 2.7 \\
\hline 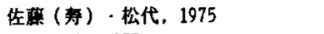 & 54 & 6 & 11.1 \\
\hline Mentouri, 1977 & 468 & 30 & 6.4 \\
\hline 槙，1978 & 71 & 4 & 5.6 \\
\hline 小野, 1986 & 140 & 1 & 0.7 \\
\hline
\end{tabular}

表 2 愁訴例

(1)

\begin{tabular}{|c|c|c|c|c|c|c|c|c|}
\hline \multirow[b]{2}{*}{ 䒠间 } & \multirow{2}{*}{ 年䜾 } & \multirow[b]{2}{*}{ 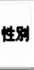 } & \multirow{2}{*}{ 原察 } & \multirow{2}{*}{ 亚 } & \multicolumn{2}{|c|}{ 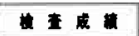 } & \multirow{2}{*}{ 的年数 } & \multirow{2}{*}{ the } \\
\hline & & & & & 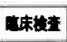 & $\begin{array}{l}\text { ENGP.UE } \\
\text { GT-scan }\end{array}$ & & \\
\hline 1 & 37. & 女 & 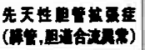 & 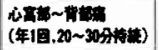 & 军萦なし & 声石(一) & 12 年 & 해풀 \\
\hline 2 & 48: & 女 & 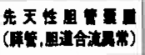 & 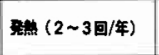 & "I & is & 7年6力月 & $i$ \\
\hline 3 & 63: & 女 & 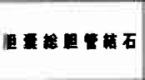 & 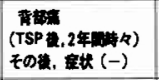 & " & $\mathrm{N}$ & 8年 & 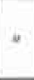 \\
\hline 4 & 6014 & 女 & 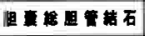 & 箠炎 (1固) & 4 & n & 6年 & $"$ \\
\hline 5 & $48 \mathrm{Aa}$ & $n$ & 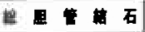 & 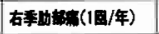 & $*$ & " & 11年 & n \\
\hline
\end{tabular}

(2)

\begin{tabular}{|c|c|c|c|c|c|c|c|}
\hline 庭型 & 年"⿻ & 性别 & 原实 & 轱识年数 & 在 淽 & 是 管 & 治 表 \\
\hline 1 & $65^{1 / 2}$ & 女 & 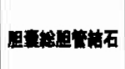 & 12年9カ月 & 国管资( 1 回) & & $\begin{array}{l}\text { PTCS-L } \\
\text { 物石完T }\end{array}$ \\
\hline 2 & 44: & 查 & 居内告石 & 7年5カ月 & 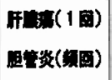 & & $\begin{array}{l}\text { PTCS-L } \\
\text { 切石完了 }\end{array}$ \\
\hline 3 & 43: & s & 开内蔽石 & 12年10力月 & 策炎(2回/年) & & PTCS-L \\
\hline 4 & 43:2 & 女 & 年内薄石 & 7 年 & 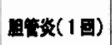 & & sing \\
\hline
\end{tabular}

作り成果をあげている(健光社)，現在までのところ表 1 のごとく手術直接死亡率は $0.7 \%$ で諸家の成績にく らべて安全な方法といえよう。

TSP 140例中 3 年以上経過した117例について長期 経過観察したところ, 生存86例のらち無愁訴72例 (83.7\%) 有愁訴14例 (16.3\%) であった. 死亡27例の 5ち17例は脳卒中, 心不全その他による病死, 8 例が
肝・胆道系疾患でその5ち 3 例が肝癌, 1 例が肝膿汪 であった. また長期 follow up 117例の疾患別内訳では 110例が胆道系，17例は慢性荤炎であった。

有愁訴例14例の内訳では慢性膵炎, 肝内結石に多い 傾向がみられた。慢性荤炎は病変が乳頭部のみに限局 していないので, 手術適応の決定については慎重な配 慮が必要であろ5. 慢性荤炎の 5 例を除外した 9 例に ついて検討すると表 2 のごとく，荤管胆道合流異常, 胆管結石など 5 例は愁訴を有するとはい光，いずれる 就業して和り，とくに本質的な問題点をかかえていな いようである（表 2-1）。残る4例はいずれす肝内結 石症例で 3 次分枝より上流の肝内胆管にいずれす結石 の遺残を認めたので, PTCS-Lつまり経皮経肝による 胆道鏡的截切術を行ない，問題解決を完了しつつある (表 $2-2$ ).

以上の結果から本術式をめぐる問題点がおのづから 浮び上ってくるものと思われる。すなわち TSP 禁忌 として 1) 慢性荤炎, 2) 肝内結石とくに肝内狭窄を伴 らもの，の2つをあげることがでさよら。この 2 点は 以前より著者の強調するところである。

\section{むすび}

以上 Oddi 笳の外科臨床について未解決の問題点を 多く残しつつ稿を終ることになるが，1986年は Oddi の生誕122年に当る. また彼の Perugia 大学医学部 4 年時の括䄪筋発見の原著8)91公刊から99年目に当る.

著者ら ${ }^{916)}$ は1984年 Perugia 市民からる忘れ去られ ていた彼の生家(Perugia 市 Bruschi 通り13番地)を発 見した. 1984年は彼の生誕120年にも当るので, 著者ら の提言に触発され，その年を記念して市議会はOddi 広場（Piazza Ruggero Oddi）の開設を決定したとい 5.来る1987年は括約筋発見100年記念といらことで世 界的にも彼の業績顕彰とあわせて Oddi 筋の外科の確 立を期待してやまない。

\section{文献}

1）小野慶一：十二指腸乳頭部を中心とした胆道の生 理と病態. 日消外会誌 $16: 745-757,1983$

2）春山茂雄：総胆管末端部筋の運動に関する研究 一特にヒトの無胆変下, 低流量灌流時に括ける運 動について一. 日外会誌 $82: 1468-1484,1981$

3) Toouli J, Geenen JE, Hogan WJ et al: Sphincter of Oddi motor activity: A comparison between patients with common bile duct stones and control. Gastroenterology $82: 111-117$, 1982

4) Scott RB, Strasberg SM, El-Sharkawy TY et 
al: Fasting canine biliary secretion and the sphincter of Oddi. Gastroenterology $87: 793$ $-804,1984$

5) Ono $K$, Watanabe $N$, Suzuki $K$ et al: Bile flow mechanism in man. Arch Surg 96 : 869-874, 1968

6) Ono K, Suzuki H, Hada R et al : Gastrointestinal hormones and motility of the human sphincter of Oddi. Jpn J Smooth Muscle Res 21(Suppl) : 69-75, 1985

7) Arndorfer RC, Stef JJ, Dodds WJ et al: Improved infusion system for intraluminal esophageal manometry. Gastroenterology 73 : 23-27, 1977

8) Oddi R: Di una speciale disposizione a sfintere allo sbocco del coledoco. Annali dell' Universita Libera di Perugia 2 : 249-264, 1887

9）小野慶一, BOZ 白杵 淑：総胆管開口部に存在寸 る特殊な括約筋機構について。ルッシェーロ・オッ デイ (医学部 4 年時) の研究. 胆と䐙 $6: 1677$ $-1686,1985$ 8) の邦訳

10) Boyden EA : The anatomy of the choledochoduodenal junction in man. Surg Gynecol Obstet $104: 641-652,1957$

11) Szurszewski JH: A migrating electric complex of the canine small intestine. Am J Physiol 217: 1757-1763, 1969

12) Sarna SK: Cyclic motor activity: migrating motor complex : 1985. Gastroenterology 89 : $894-913,1985$

13）伊藤 漸：消化管平滑筋の構造と機能の基礎。 B.
無拘束意識下の観察. 三好秋馬, 伊藤 漸編. 消化 管運動機能調節剂一基礎と臨床一. 東京, 医薬 シャーナル社, 1985, p75-97

14）田中丈二：胆汁排出機序に関する研究一十二指腸 および総胆管末端部の電気生理学的研究. 日平滑 筋会誌 $1: 50-71,1965$

15）小林粅三, 三谷栄時, 山田英明：胆道末端筋の運動 様式一胆汁排出機序に関して, 運動充進説の立場 から. 胆と膆 $2: 29-35,1981$

16）小野度一：Ruggero Oddi と Oddi 括約筋の今日 的意義。日平滑筋会誌 $21: 369-385 ， 1985$

17）小野度一, 鈴木英登士, 百田行雅注か：Caerulein, CCK 負荷の際の Oddi筋運動. 臨成人病 16 : 1411-1413, 1986

18）小野度一,高橋賢一，森達也ほか：胆道ジスキネ ジー一その基礎的研究としての肝外胆汁排出動態 の钼察。臨之研 62:2436-2441，1985

19）小野度一, 遠藤正章, 佐々木㓐男的：経十二指腸 括約筇形成術。消外 $8: 1097-1106,1985$

20）小野度一：Oddi 筋の外科. 木本誠二監修. 現代外 科学大系年刊追補. 1976-C, 東京, 中山書店, 1976, p $227-286$

21）小野慶一：Vater 乳頭切開術の適応之術式. 尾形 利郎, 戸部隆吉, 堀原一多編。今日の臨床外科. 第 8 巻, 東京, メジルビュー社, 1979, p179-199

22）小野慶一：乳頭の切開・形成, 胆道狭窄の手術. 木 本誠二監修. 現代外科手術学大系. 14巻, 東京, 中 山書店, 1979, p141-162

23) Sorcetti F : Ruggero Oddi medico e scienziato perugino. Rivista di Biologia 78 : 133-140, 1985 